\title{
PROBLEM OF ACCIDENT RECONSTRUCTION MECHANISM USING PARAMETERS OF BRAKING PROCESS OF TWO-WHEELED MOTOR VEHICLES.
}

\author{
Stanislav Evtyukov¹, Grigory Ginzburg², llya Brylev³ \\ ${ }^{1,3}$ Saint Petersburg State University of Architecture and Civil Engineering, \\ Vtoraja Krasnoarmejskaja ul. 4, St. Petersburg, 190005, Russia. \\ ${ }^{2}$ Vigrig Inc. \\ 1ese-89@yandex.ru, ${ }^{3}$ ilya2104@mail.ru
}

\begin{abstract}
Increase in the number of two-wheeled motor vehicles (motorcycles, vehicles of category L3) is observed in the traffic of almost all countries in the world. That is why the number of victims and people seriously injured in the road traffic accidents (RTA) has considerably increased. The majority of RTA is the result of many factors which form together sets of different causes and effects. Identification of actual reasons having led to a traffic accident, as well as their attendant circumstances, is one of the most important tasks in ensuring traffic safety. On the one hand, configurations of twowheeled motor vehicles have been significantly improved over the last decades, so it is necessary to align the analytical apparatus of estimating parameters of the braking process with these configurations. On the other hand, the current practice of expert analysis and settlement of accidents still involves estimation of increase in braking time and steady deceleration of motorcycles manufactured domestically during the past years, which hardly participate in the modern traffic due to their age. Both of these circumstances require review and adjustment, as well as formation of an updated basis of estimate for assessment of braking processes of two-wheeled motor vehicles in order to increase the reliability of RTA examination and determine compliance or non-compliance of driver's actions with the requirements of traffic rules, establish the causes of accidents, evaluate a technical capability of a driver of the two-wheeled motor vehicle to prevent the accident. Settlement of all these issues can be provided by effective methods of calculation (quantitative) assessment, which are not available at the present moment.
\end{abstract}

Key words: technical expertise of vehicles, two-wheeled motor vehicles, calculation of speed, deceleration

\section{Introduction}

The common method of braking speed calculation for two-wheeled motor vehicles (TWMV) established in the 1960s of the previous century that is still applied in the Russian Federation has some drawbacks involving among others the issue of calculation of braking speed of the TWMV according to tire burns which underestimates the rated speed.

The expert evidence revealed that the actual speed of the TWMV at the beginning of braking is higher than the calculated rate, as a rule, because experts obviously use underestimated and averaged values of steady deceleration and the time of braking rise up to a steady-state deceleration.

The current procedure of calculation of speed and braking rates, stopping distance, braking time, distance from the impact point at the hazardous moment of movement does not allow for optional antilock brake system (ABS), the type of braking system and variable load rates of the motorcycle that impact obtained assessment values of steady-state deceleration of the TWMV and the time of deceleration rise. 
Taking into account the above said, the expert's experience suggests that the method of estimation of braking parameters during RTA reconstruction considers the above-mentioned configuration features of TWMV and traffic conditions during braking (during the closest customizing to the investigated RTA in whole) which makes it possible to bring this method in line with the modern configuration of TWMV allowing improving considerably the accuracy of braking estimates and objectivity of these estimates (Brylev, 2014, 2015; Evtyukov, Brylev, 2013a, 2015; Guo et al., 2008; Obenski, 1994).

\section{Scope, Objectives and Methodology}

During the braking tests and analysis of their results, the authors revealed that the following factors affect to a greater extent the value of steady-state deceleration of the TWMV and the time of deceleration rise: availability of ABS, type of braking (manual, foot control or simultaneous action of foot and manual braking), load rates of the TWMV, type of the brake system and conditions of the road surface.

A pictorial diagram of the braking process of the motorcycle Yamaha XVS 1100 Drag Star Classic on dry asphalt pavement performed with the help of decelerometer software LWS-2MC is shown on Figure 1 (taken adhesion coefficient was about 0.8 under combined braking and unladen weight).

Figure 1. Braking diagram of the motorcycle Yamaha XVS 1100 Drag Star Classic under a combined type of braking, unladen weight and adhesion coefficient equaling 0.8

\section{Results and Discussion}

According to results of analyzing the values of steadystate braking of the vehicle of category L3 and the time of its rise, which are the main characteristics of motorcycle braking impacting the result of the RTA reconstruction (i.e. calculation estimation of technical possibility to prevent a road traffic accident), it can be stated that expert organizations have information on motorcycle deceleration values calculated by the All-Union Scientific Research Institute of Judicial Investigation of the Soviet Union (AUSRIJI USSR) more than 35 years ago (Arabuli, 1990; Brylev, 2014, 2015; Evtyukov, Brulev, 2013a, 2014, 2015, 2016; Krinitsyn, 1987).

A lot of factors influence the value of steady-state deceleration (j) and the time of deceleration rise up to steadystate (t3), such as technical state of the TWMV (condition of the brake system, condition of tires, availability of ABS or auxiliary braking systems, etc.), conditions of the road surface (wheel tracking, roughness, temperature and type of roadbed, etc.).

The analysis of drawbacks of the current procedure of braking estimation considered such parameters traditionally applied during reconstruction of RTA as stopping distance (So), speed before braking (Va), distance from the impact point (Sy), time of stopping (To) and permissible speed according to visibility conditions (Vdv). The analysis revealed that standard values of steady-state deceleration and time of its rise do not allow for the type of brake system of the TWMV, intermediate load of the motorcycle and availability of $A B S$, impacting the values of braking parameters (Brylev, 2014; Evtyukov, Brulev, 2013a, 2014, 2015).

Results of comparative assessment of values of steady-state deceleration and time of steady-state deceleration rise received during experimental studies and those established and approved by the Scientific and Methodological Board for judicial technical expertise of vehicles by the All-Union Scientific Research Institute of Judicial Investigation of the Soviet Union and enacted as of January 1st, 1991, also established by GOST 41.782001, revealed that the values of steady-state deceleration of the TWMV and time of steady-state deceleration rise are significantly underrated (Brylev, 2015; Evtyukov, Brulev, 2014, 2015; Guo et al., 2008; Obenski, 1994). This is due to the fact that applied reference values were established without consideration of significant changes in configuration of TWMV, its reliability and other performance properties. The Russian expertise practice does not allow for new configurations of TWMV in calculations recommended for use during investigations and recon-

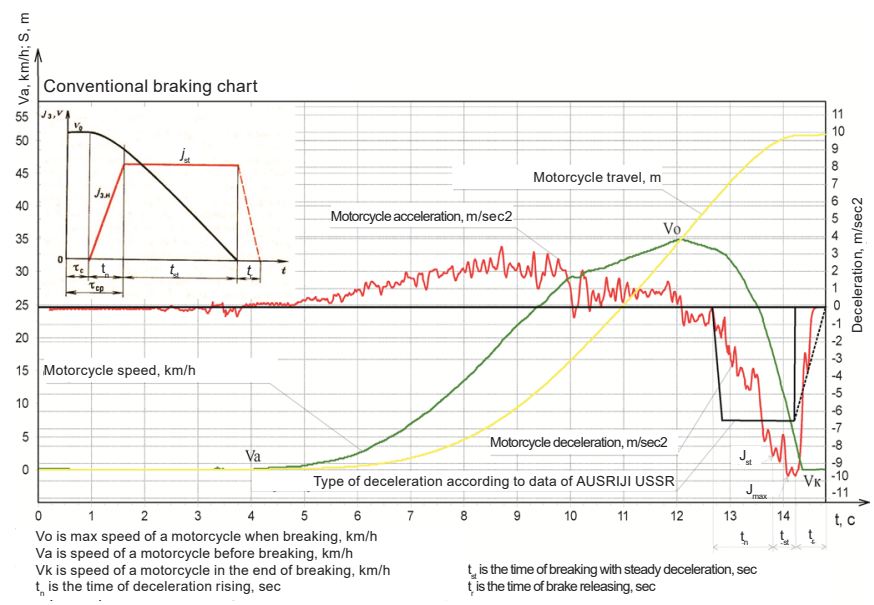

Figure 1. Braking diagram of the motorcycle Yamaha XVS 1100 Drag Star Classic under a combined type of braking, unladen weight and adhesion coefficient equaling 0.8 
struction of RTA and identification of stopping distances, distance of the TWMV from the impact point, speed rate at the beginning of braking, stopping time and speed limits according to visibility conditions.

During experimental studies, they assessed the impact of the above stated factors on values of steady-state deceleration (j) and the time of deceleration rise up to the steady-state value ( $\mathrm{t} 3)$. Besides, they justified the necessity to take into account the availability of ABS in the configuration, the type of braking system, variable loads of the TWMV, braking mode in dependence to the road surface at the time of the RTA. In this regard, it is reasonable to introduce test coefficients $\mathrm{Kj}$ and $\mathrm{Ki}$ when selecting the value of steady-state deceleration and the time of its rise in order to correct these values taking into account parameters of braking mode, type of the braking system of the TWMV, conditions and type of the road surface, availability of the ABS and variable value of the TWMV loading. Taking into account the mentioned factors, calculation constraints of braking process parameters during the RTA reconstruction would be as follows (Brylev, 2014, 2015; Evtyukov, Brulev, 2013a, 2014, 2015):

- stopping distance of the TWMV, m:

$$
S_{\mathrm{o}}=\left(t_{1}+t_{2}+0,5 \cdot t_{3} \cdot K_{i}\right) \frac{V_{\mathrm{a}}}{3,6}+\frac{V_{\mathrm{a}}^{2}}{26,0 \cdot j \cdot K_{j}}
$$

- speed of the TWMV at the beginning of breaking

$$
V_{\mathrm{a}}=1,8 \cdot t_{3} \cdot K_{i} \cdot j \cdot K_{j}+3,6 \cdot \sqrt{2,0 \cdot j \cdot K_{j} \cdot S_{\mathrm{wo}}}
$$

with recorded tire burns, $\mathrm{km} / \mathrm{h}$ :

- distance of the TWMV from the impact point, $\mathrm{m}$ :

$$
S_{\mathrm{y}}=\left(t_{1}+t_{2}+0,5 \cdot t_{3} \cdot K_{i}\right) \cdot \frac{V_{\mathrm{a}}}{3,6}+S_{t}
$$

- stopping time of the TWMV, sec:

$$
T_{\mathrm{o}}=\left(t_{1}+t_{2}+0,5 \cdot t_{3} \cdot K_{i}\right)+\frac{}{3,}
$$

- permitted speed of the TWMV according to visibility conditions, $\mathrm{km} / \mathrm{h}$ :

$$
\begin{aligned}
& V_{\text {дв }}=3,6 \cdot \sqrt{\left(j \cdot K_{j} \cdot\left(t_{1}+t_{2}+0,5 \cdot t_{3} \cdot K_{i}\right)\right)^{2}+2 \cdot j \cdot K_{j} \cdot S_{\text {в }}}- \\
& -3,6 \cdot j \cdot K_{j} \cdot\left(t_{1}+t_{2}+0,5 \cdot t_{3} \cdot K_{i}\right)
\end{aligned}
$$

where $\mathrm{Kj}$ is an adjustment coefficient for the TWMV deceleration; $\mathrm{Ki}$ is an adjustment coefficient for the time of deceleration rise of up to steady-state value; $\mathrm{t} 1$ is the time of driver's reaction, sec; $t 2$ is the braking response time, sec; $\mathrm{t} 3$ is deceleration speed rising up to steadystate value, sec; $j$ is steady deceleration, $\mathrm{m} / \mathrm{sec} 2$; $\mathrm{ST}$ is tire burns of the TWMV from their beginning to the impact point, $\mathrm{m}$; $\mathrm{Va}$ is speed at the moment of the driver's decision to brake; Sю is braking burns, m; SB is visibility from the driver's seat.

Results of experimental studies of steady deceleration (j) and the time of its rise (t3) revealed that their actual values for the majority of recent TWMV are much higher than the standard values recommended for use during technical studies of vehicles. When calculating technical ability of the driver to prevent an RTA, it is reasonable to use actual value of steady deceleration and the time of its rise established in the course of field studies instead of standard values.

The expert experience does not allow in most cases to determine the actual value of steady deceleration and the time of its rise (yopj) and (yopi) at the moment of the RTA. In such cases, it is advisable to compare reference values of deceleration (унј) and the time of its rise (уні) with the prescribed ones (ypj) and (ypi) in order to settle boundary value problems. If $(\mathrm{yH}) \geq(\mathrm{yp})$, then the measured value cannot affect the value of steady deceleration or the time of deceleration speed rising, and if $(\mathrm{yH})<(\mathrm{yp})$, then the measured value influences the value of steady deceleration or the time of its rise (Brylev, 2015; Evtyukov, Brulev, 2015).

If there is a possibility to calculate the actual value of

$$
K_{i, j}=\frac{y_{\phi_{i, j}}}{y_{u_{i, j}}}
$$

steady-state deceleration of a vehicle of category L3 and the time of deceleration value rising immediately after the accident, then coefficient Ki,j can be calculated according to the following equation:

If there is no possibility to estimate the actual value of

$$
K_{i, j}=\frac{y_{p_{i, j}}}{y_{u_{i, j}}}
$$

steady-state deceleration of a vehicle of category $L 3$ and the time of deceleration value rising immediately after the accident, then the coefficient Ki,j can be calculated according to the following equation:

Conclusion. According to the above said, actual values of steady-state deceleration determined during test studies for the TWMV on road surfaces with different adhesion coefficients turned out to be higher as compared to the reference values by an average of $20-25 \%$; actual values of the time of deceleration rising up to a steady-state value turned out to be higher, than the existing reference values by 2-3 times on average.

Standard averaged values of steady deceleration and the time of its rise were adjusted, which allowed updating the procedure of reconstruction of the RTA depending on the type of brake system of the TWMV, the weight of the TWMV, type and condition of the road surface, availability of $A B S$ and the braking mode. 


\section{References}

Arabuli YG (1990) Ispol'zovanie v jekspertnoj praktike jeksperimental'no-raschetnyh znachenij parametrov tormozhenija mototransportnyh sredstv: metod. rekomendatsii [The use of calculated values of motorcycle braking in expert practice: guidelines]. AUSRIJI, Moscow, RF (in Russian).

Brylev IS (2014) Otsenka pogreshnosti raschetov skorosti dvizhenija motociklov na stadii sblizhenija [Error estimation of motorcycle speed on the approach stage]. Vestnik grazhdanskikh ingenerov [Bulletin of Civil Engineers], 6 (47): 178-182 (in Russian).

Brylev IS (2015) Jeksperimental'nye issledovanija parametrov zamedlenija transportnyh sredstv kategorii L3 [Experimental studies of deceleration parameter of the vehicles of category L3]. Vestnik grazhdanskikh ingenerov [Bulletin of Civil Engineers], 2 (49): 131-137 (in Russian).

Evtyukov SA, Brylev IS (2013b) Problemy provedeniya avtotekhnicheskikh ekspertiz s uchastiem mototsiklistov [The problems of technical expertise of vehicles involving motorcyclists]. Fundamental'nye i prikladnye nauki [Fundamental and Applied Science], without No.: 125-129.

Evtyukov SA, Brylev IS (2014) Jeksperimental'nye issledovanija parametrov ustanovivshegosja zamedlenija i tormoznogo puti transportnyh sredstv kategorii L3 [Experimental studies parameter is set deceleration and stopping distance of motorcycles]. Mir transporta i tekhnologicheskikh mashin [Transport and Technological Cars], 4(47): 125-130 (in Russian).

Evtyukov SA, Brylev IS (2015) Algoritm korrektirovki normativnyh znachenij vremeni narastanija zamedlenija, ustanovivshegosja zamedlenija dvuhkolesnyh mehanicheskih transportnyh sredstv [Corraction algorithms normative values rise time deceleration, set deceleration motorized two wheelers]. Mir transporta i tekhnologicheskikh mashin [Transport and Technological Cars], 3(50): 3-12 (in Russian).

Evtyukov SA., Brylev IS (2013a) Obzor sushhestvujushhih metodik rascheta skorosti dvuhkolesnyh transportnyh sredstv [Review of existing methods calculation speed of two-vehicles]. Sovremennye problemy nauki i obrazovaniya [Modern problems of science and education],n. 6, URL: www.science-education.ru/113-10750 (accessed 21.06.2016) (in Russian).

Evtyukov SS, Brylev IS (2016) Raschetnaya otsenka parametrov protsessa tormozheniya transportnykh sredstv kategorii L3 pri rekonstruktsii DTP [Estimated of braking process parameters of category L3 vehicles at reconstruction of the road accident] Vestnik grazhdanskikh ingenerov [Bulletin of Civil Engineers], 2(55): 181-185 (in Russian).

Guo L, Jin XL, Zhang XY, Shen J, Chen YJ, Chen JG (2008) Study of injuries combining computer simulation in motorcycle-car collision accidents. Forensic Science International, 177(2-3): 90-96.

Krinitsyn AA (1987) Primenenie normativnykh znachenii parametrov tormozheniya mototransportnykh sredstv $v$ ekspertnoy praktike: metod. rekomendatsii [Expert practice use of standard parameters of braking for motorcycle vehicles: methodological guidelines]. AUSRIJI, Moscow, RF (in Russian).

Obenski Kenneth S (1994) Motorcycle Accident Reconstruction: Understanding Motorcycles. Lawyers \& Judges Publishing Co.

Puchkin VA (2010) Osnovy jekspertnogo analiza dorozhno-transportnyh proisshestvij: Bazy dannyh. Jekspertnaja tehnika. Metody reshenij [Basics of expert analysis of road traffic avccidents: databases, expert techniques, methods of decision making]. Institute of Postgraduate Education of Southern Federal University, Rostov-on-Don, RF (in Russian). 